\title{
Recenzja książki Niezwyczajni ludzie. Nowe spojrzenie na autyzm, Barry M. Prizant, Tom Fidels-Meyer, Wydawnictwo Uniwersytetu Jagiellońskiego, Kraków 2017
}

Zaburzenia ze spektrum autyzmu od wielu lat budzą ogromne zainteresowanie naukowców na całym świecie. Pomimo wielu interesujących doniesień, badacze wciąż poszukują odpowiedzi na nurtujące pytania w powyższej dziedzinie. Wśród nich znajduje się również Barry Prizent i jego współpracownicy (m.in. Amy Wetherby, Emili Robin i Amy Laurent), którzy opracowali model SCERTS (Social Comunication, Emotional Regulation and Transactional Support) ${ }^{1}$. Powyższy model zawiera wskazówki dla rodziców, pedagogów oraz terapeutów dotyczący pracy z dziećmi z zaburzeniami ze spektrum autyzmu. Ponadto Prizent prowadzi wieloletnie obserwacje i badania nad zjawiskiem echolalii jako drogi do opanowania języka. Jeździ po całym świecie z wykładami, warsztatami i szkoleniami, dzięki czemu jego działalność ma charakter uniwersalny, zrozumiały dla wszystkich społeczności kulturowych.

Niezwyczajni ludzie. Nowe spojrzenie na autyzm to książka, która jest wynikiem czterdziestoletniej działalności naukowej autora. Powstała przy współudziale wielu ludzi, (m.in. współautora Toma Fidels-Meyera, wieloletniego współpracownika, przyjaciela Barrego Prizanta). Niezwykle naładowana emocjonalnie, mądra, zachęcająca do zmiany w naszym postrze-

${ }^{1}$ B.M. Prizant, Tom Fidels-Meyer, Niezwyczajni ludzie. Nowe spojrzenie na autyzm, Wydawnictwo Uniwersytetu Jagiellońskiego, Kraków 2017, s. 243. 
ganiu ludzi dotkniętych zaburzeniami ze spektrum autyzmu. Prizent już w swojej krótkiej przedmowie kładzie ogromny nacisk na znaczenie pracy terapeutycznej z osobami ze spektrum autyzmu (komunikacja społeczna, stabilność emocjonalna, interakcje z innymi). Według danych Amerykańskich Centrów Kontroli Chorób (Centers for Disease Control) autyzm należy obecnie do najczęściej diagnozowanych zaburzeń rozwoju. Dotyka on aż jedno na 50 dzieci w wieku szkolnym². Jednak w sposób krytyczny odnoszę się do słów (niejednokrotnie przewijających się w tekście, np. s. 14, 17) określania autyzmu mianem choroby (?/!), która wymaga odpowiedniego leczenia. Przecież definicja autyzmu (zgodnie z obowiązującą, min. w Polsce Międzynarodową Klasyfikacją Zaburzeń Psychicznych i Zaburzeń Zachowania ICD-10 z 1993r) mówi wyraźnie:

autyzm to całościowe zaburzenie rozwoju charakteryzujące się nieprawidłowym i/lub upośledzonym rozwojem, pojawiające się przed 3. rokiem życia, w którym występuje nieprawidłowe funkcjonowanie we wszystkich spośród trzech sfer: interakcjach społecznych, komunikacji oraz ograniczonym, powtarzającym się repertuarze zachowań3 ${ }^{3}$.

Mimo tej nieścisłości (być może niewłaściwy przekład z języka angielskiego na język polski), nie sposób nie zgodzić się z autorem, że należy zmienić nasze postrzeganie osób dotkniętych autyzmem. Lektura książki ma przynieść nowy paradygmat w pedagogice specjalnej:

zamiast klasyfikować dozwolone, funkcjonalne zachowania jako oznakę patologii, zbadamy je jako część wielu strategii pomagających w radzeniu sobie, adaptowaniu się, komunikowaniu się i stawianiu czoła światu, który przytłacza takie osoby i budzi w nich strach - i dalej ...jak stworzyć strategie radzenia sobie z problemami i zaoferować pomoc, dzięki której będzie można zapobiec niepokojącym wzorcom zachowań i naturalnie doprowadzić do tych bardziej pożądanych?4

Zatem zamiast odrzucać „autystyczne”, „niewłaściwe” zachowania, należałoby raczej zapytać: jaką pełnią funkcję?

2 Ibidem, s. 15.

${ }^{3}$ E. Pisula, Autyzm. Przyczyny. Symptomy. Terapia, Wydawnictwo Harmonia, Gdańsk 2016 - Wydanie IV, s. 33.

4 B.M. Prizant, Tom Fidels-Meyer, op. cit., s. 17. 
Całość książki podzielona jest na dwie zasadnicze części. Pierwsza część: „Zrozumieć autyzm: zawiera sześć rozdziałów: „Zapytaj dlaczego?”, „Słuchaj”, „Fascynacje”, „Zaufanie, strach i kontrola”, „Pamięć emocjonalna", "Zrozumienie społeczne". Niewątpliwie poruszane kwestie otwierają serca czytelników i inspirują do zgłębienia i przede wszystkim zrozumienia autyzmu. Na szczególną uwagę zasługują dwie poruszane kwestie: umiejętność słuchania oraz zjawisko echolalii. Słuchanie jest podstawą prawidłowej komunikacji. Jeżeli nie potrafimy słuchać, dzieci które nie komunikują się w sposób werbalny, wpadają w frustrację, złość, która $\mathrm{z}$ kolei nie jest wynikiem agresji, lecz próbą komunikacji. Raun Kaufman (pierwsze dziecko Programu Son-Rise) ${ }^{5}$ wykazuje, że dzieci z autyzmem mówią w języku "obcym” (porównanie do szwedzkiego), dla nas niezrozumiałym. Barry Prizent, przez wiele lat obserwując osoby $\mathrm{z}$ autyzmem, badał zjawisko echolalii. Dowiódł, że taki rodzaj mowy (komunikowania), to nie jest pozbawione znaczenia "papugowanie", ale mowa werbalna, która ma swój cel. Tymczasem terapeuci, nie rozumiejąc echolalii i nakłaniając rodziców do jej zdecydowanego przerywania, powodują zahamowanie mowy. Mało tego, poprzez takie działania uniemożliwiają dziecku podejmowanie prób komunikowania się, zakłócają proces uczenia się i nawiązywania łączności ze światem.

Druga część - „Życie z autyzmem" - podzielona jest na następne sześć rozdziałów: "Co trzeba zrobić, by mieć to coś", „Mądrość grupy znajomych”, "Prawdziwi eksperci”, „Perspektywiczne spojrzenie”, „Rozbudź ducha” oraz "Ważne pytania”. Ta część niesie ze sobą bardzo ważne przesłanie: „Z autyzmu się nie wyrasta - tłumaczy Dena Gassner, matka, która sama dotknięta jest zaburzeniem ze spektrum autyzmu - w niego się wrasta"6.

Niesłychanie cenne są historie rodzin, które dzielą się doświadczeniami, jakie nabyły poprzez wspólne (trudne) dorastanie ich dzieci od okresu wczesnego dzieciństwa poprzez okres przedszkolny, nastoletni aż po dorosłość. To niesamowity traktakt o sile miłości, zrozumienia, akceptacji i ogromnego szacunku. Rodzice, którzy dowiedzieli się, że ich dziecko ma autyzm, stają się w pierwszym momencie osamotnieni, wyizolowani. Na2016.

${ }^{5}$ R.K. Kaufman, Autyzm przełom w podejściu. Wydawnictwo Vivante, Białystok

${ }^{6}$ Barry M. Prizant, Tom Fidels-Meyer, Niezwyczajni ludzie. Nowe spojrzenie na autyzm, Wydawnictwo Uniwersytetu Jagiellońskiego, Kraków 2017, s. 190. 
gle ludzie, którzy byli w ich dotychczasowym życiu, wycofali się. Barry Prizant przez pryzmat czterdziestoletniego doświadczenia nakreśla nowe ścieżki pracy terapeutycznej, pomaga $\mathrm{w}$ osiągnięciu sukcesów na miarę możliwości dzieci, a w przyszłości dorosłych z autyzmem.

Język, którym posługuje się autor (mimo trudnego zagadnienia dotyczącego autyzmu), jest przystępny, zrozumiały. Dociera do szerokiego grona odbiorców (nauczycieli, terapeutów, rodziców). Lektura książki daje nowe spojrzenie na autyzm jako „niezwykły wymiar człowieczeństwa”.

Uważam, że publikacja, dostarczając nowych treści wzbogaconych o dane $z$ badań własnych autora i jego długoletnich obserwacji, stanowi cenny wkład w dziedzinę. 